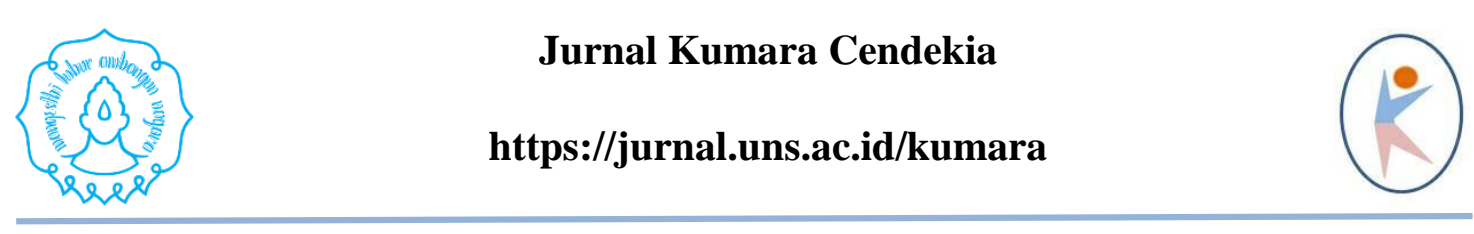

\title{
PENINGKATAN KEMAMPUAN BERBICARA MELALUI ROLE PLAY PADA ANAK USIA 5-6 TAHUN
}

\author{
Citra Fitriyani $^{1}$, Siti Kamsiyati ${ }^{2}$, Adriani Rahma Pudyaningtyas ${ }^{1}$ \\ ${ }^{1}$ Program Studi PG-PAUD, Universitas Sebelas Maret Surakarta \\ ${ }^{2}$ Program Studi PGSD, Universitas Sebelas Maret Surakarta
}

Email : citrafitriyani97@gmail.com, sitikamsiyati@staff.uns.ac.id, adriani.rahma@staff.uns.ac.id

\begin{abstract}
ABSTRAK
Penelitian ini bertujuan untuk meningkatkan kemampuan berbicara melalui metode role play. Jenis penelitian ini adalah penelitian tindakan kelas (PTK) dilaksanakan selama tiga siklus. Subjek dalam penelitian ini adalah anak usia 5-6 tahun dengan jumlah 32 anak yang terdiri dari 16 anak perempuan dan 16 anak laki-laki. Teknik pengumpulan data dalam penelitian ini menggunakan unjuk kerja, observasi, wawancara dan dokumentasi. Teknik uji validitas data yang digunakan adalah triangulasi sumber dan triangulasi teknik. Hasil penelitian tindakan kelas ini menunjukkan bahwa melalui metode role play, anak dapat menyusun kalimat sederhana dalam struktur lengkap, mampu berkomunikasi secara lisan, dan menjawab pertanyaan yang lebih kompleks. Hasil keseluruhan peningkatan persentase setelah diterapkan metode role play, pada siklus I diperoleh ketuntantasan sebesar 40,62\%. Peningkatan persentase pada siklus II sebesar 56,62\%, dan pada siklus III sebesar 78,12\%. Berdasarkan uraian tersebut maka dapat ditarik kesimpulan bahwa melalui metode role play dapat meningkatkan kemampuan berbicara pada anak usia 5-6 tahun.
\end{abstract}

Kata kunci: Kemampuan berbicara, metode role play, anak usia dini

\section{ABSTRACT}

This research aimed to improve speaking ability through role play methods. This type research is Classroom Action Research (CAR), were conducted in three cycles. The subject in this research were 32 children consisted of 16 girls and 16 boys. The technique of data collection in this research used by work performance, observation, interviews, and documentation. Analyzed test the validity of the data used is a triangulation of sources and triangulation techniques. Research result show that class actions through role play methods, children can compose simple sentences in a complete structure, be able to verbal communicate, and answer more questions complex. The overall result show increase in the percentage after applied role play methods, in the first cycle acquired $40.62 \%$. The percentage increase in the second cycle was $56.62 \%$, and the third cycle by $78.12 \%$. Based on the descriptions can be drawn the conclusion that through role play methods could increase the speaking ability children aged 56 year.

Keywords: Speaking ability, role play methods, early childhood 


\section{PENDAHULUAN}

Perkembangan bahasa adalah salah satu aspek penting yang harus dimiliki pada perkembangan anak usia dini. Masa kanakkanak merupakan usia yang paling tepat dalam mengembangkan aspek bahasa, sebagai salah satu dari kemampuan dasar sesuai pada tingkatan usia dan karakteristik perkembangan anak. Bleses, dkk (2018) menjelaskan mengenai peran bahasa memiliki manfaat penting pada perkembangan anak usia dini yang dapat digunakan untuk mengidentifikasi serta memantau tahap pengembangan bahasa anak sesuai dengan tingkat perkembangannya.

Seefeldt dan Wasik (2008) menjelaskan bahwa anak-anak terlibat dalam empat keterampilan berbahasa, meliputi mendengarkan, berbicara, membaca, dan menulis. Kemampuan berbicara berkaitan dengan kegiatan memproduksi ide, merupakan suatu kemampuan yang dimiliki seseorang untuk mengeluarkani ide, gagasan, ataupun pikirannya kepada orang lain melalui bahasa lisan (Abidin, 2012).

Permendikbud No. 137 Tahun 2013 menjelaskan mengenai Standar Nasional PAUD bahwa kemampuan berbicara anak meliputi menyusun kalimat sederhana dalam struktur yang lengkap yaitu menyusun kalimat berdasarkan pola SPOK
KUMARA CENDEKIA Vol. 7 No. 4 Desember 2019 seperti kalimat "anak sedang bermain sepak bola di lapangan", anak mampu berkomunikasi secara lisan dalam menyebutkan beberapa peran atau pekerjaan serta atribut yang digunakan dalam kegiatan pembelajaran seperti menyebutkan tugas seorang masinis, teknisi, kondektur dan pramugara. Anak juga mampu menjawab pertanyaan kompleks mengenai $5 \mathrm{~W}+1 \mathrm{H}$ (apa, siapa, dimana, kapan, mengapa, dan bagaimana).

Hasil observasi pada anak kelompok B di TK Gayabaru III Surakarta menunjukkan fakta bahwa belum berkembangnya kemampuan berbicara anak kelompok B. Hal ini menyatakan bahwa ada beberapa anak yang belum mampu dalam menyusun kalimat berdasarkan pola S-P-O-K dengan struktur kalimat yang lengkap, beberapa anak belum mampu berkomunikasi secara lisan dalam menyebutkan beberapa peran atau pekerjaan serta atribut yang digunakan dalam kegiatan pembelajaran, dan terdapat anak belum mampu menjawab pertanyaan kompleks mengenai $5 \mathrm{~W}+1 \mathrm{H}$ (apa, siapa, dimana, kapan, mengapa, dan bagaimana).

$$
\text { Penelitian Tahmores }
$$
menunjukkan bahwa role play merupakan cara untuk menciptakan komunikasi sosial, hal ini berhubungan dengan kemampuan berbicara dengan adanya suatu interaksi 
yang dilakukan oleh dua orang atau lebih. Metode Role play memberikan suatu kontribusi yang sangat diperlukan pada saat anak berada dalam suatu lingkungan sosial, sehingga anak akan mampu menemukan jati diri atau sosok pada diri yang mampu dia kerjakan atau lakukan terhadap orang lain. Role play sebagai suatu cara untuk memecahkan masalah, mengembangkan sikap kreatif dan metode untuk mengurangi kecemasan.

Berdasarkan permasalahan yang telah disampaikan di atas, peneliti tertarik untuk melakukan penelitian mengenai peningkatan kemampuan berbicara melalui metode role play pada anak kelompok B TK Gayabaru III Surakarta.

\section{Kemampuan Berbicara}

Kemampuan berbicara berkaitan pada kegiatan memproduksi gagasan, sehingga gagasan yang dinyatakan adalah buah pikiran yang dihasilkan pembicara yang berasal dari pengamatan yang diperoleh anak, pengalaman yang telah dilakukan anak, dan imajinasi atau kemampuan untuk membayangkan terhadap suatu hal yang ingin disampaikan pembicara terhadap pendengar.

Kemampuan berbicara merupakan suatu kemampuan berbahasa yang berkembang di kehidupan anak usia dini, didahului dengan adanya kemampuan
KUMARA CENDEKIA Vol. 7 No. 4 Desember 2019 mendengarkan (Tarigan, 2013).

Kemampuan berbicara merupakan sarana utama untuk mampu mengerti ungkapan orang lain (Ngalimun \& Alfulaila, 2014). Soetjiningsih (2014) juga mendefinisikan bahwa kemampuan berbicara sebagai bentuk pelafalan bahasa yang digunakan untuk memberikan penjelasan tentang suatu pendapat yang dimiliki pembicara.

Data penelitian yang dipakai pada kemampuan berbicara anak meliputi beberapa indikator yaitu menyusun kalimat sederhana dalam struktur yang lengkap yaitu menyusun kalimat berdasarkan pola S-P-O-K, anak mampu berkomunikasi secara lisan dalam menyebutkan beberapa peran atau pekerjaan serta atribut yang digunakan dalam kegiatan pembelajaran, dan anak mampu menjawab pertanyaan kompleks mengenai $5 \mathrm{~W}+1 \mathrm{H}$ (apa, siapa, dimana, kapan, mengapa, dan bagaimana).

\section{Metode Role Play}

Metode role play yaitu metode yang melibatkan interaksi antara dua anak atau lebih tentang suatu topik atau situasi yang terjadi pada lingkungan sekitar (Mursid, 2017). Anak menjalankan pemain sesuai dengan tokoh yang dilakoni, dan memberikan keluasan anak untuk memainkan peran sehingga mendapatkan 
kemungkinan masalah yang harus dihadapi dalam pelaksanaan sebenarnya.

Beberapa manfaat yang dapat diambil pada kegiatan role play yaitu dapat mengembangkan keterampilan dan perilaku dalam menyelesaikan masalah yang dihadapi oleh anak pada saat permainan (Zaini, Munthe \& Aryani, 2008). Metode role play mempunyai manfaat dalam menolong anak mendapatkan jati diri pada dunia sosial dan menyelesaikan permasalahan dengan bantuan kelompok (Uno, 2012). Melatih anak untuk dapat belajar menggunakan konsep pemain sesuai pada pekerjaan atau tugas dari individu yang telah dipilihkan.

Tahap-tahap kegiatan pembelajaran dengan metode role play yang dikemukakan oleh Joyce, Weil dan Calhoun (2014) meliputi: 1) Guru menjelaskan dan menggambarkan permasalahan yang terjadi kepada anakanak; 2) Guru memilih peran atau partisipan; 3). Guru mempersiapkan peralatan; 4) Anak-anak yang belum mendapatkan jatah bermain, dapat menjadi pengamat untuk dapat memberikan masukan pada saat tahap evaluasi; 5). Tahap meminkan peran; 6) Tahap diskusi; 7) Tahap evaluasi dan kesimpulan.

Madyawati (2016) menyebutkan mengenai jenis role play dibagi menjadi 2
KUMARA CENDEKIA Vol. 7 No. 4 Desember 2019 yaitu, role play bentuk makro dan role play bentuk mikro. Role play makro yaitu anak berperan secara nyata atau sesungguhnya atau anak menirukan gaya seseorang, sedangkan role play mikro adalah permainan kerjasama yang dilakukan hanya dua orang saja bahkan sendiri dengan menggunakan media.

Peneliti memiliki alasan menggunakan metode role play makro karena dalam kegiatan tersebut anak dapat berperan secara langsung memerankan sesungguhnya menjadi tokoh tertentu, kegiatan ini sudah didapatkan anak pada pengalaman sehari-hari anak yang bertema pada sekitar kehidupan nyata, sehingga dari pengalaman tersebut anak dapat melatih diri untuk mampu mengimitasi atau meniru gaya seseorang untuk melakukan kegiatan role play.

\section{METODE}

Penelitian ini merupakan jenis penelitian tindakan kelas dengan pendekatan kuantitatif dan kualitatif. Penelitiani ini dilaksanakan dalam tiga siklus yang tiap siklusnya terdiri dari tiga kali pertemuan. Setiap siklus terdiri dari perencanaan, pelaksanaan dan pengamatan, serta refleksi. Subjek dalam penelitian ini adalah anak kelompok B TK Gayabaru III Surakarta dengan jumlah 32 anak, yang 
terdiri dari 16 anak perempuan dan 16 anak laki-laki. Sumber data dalam penelitian ini adalah anak dan guru.

Teknik pengumpulan data dalam penelitian ini menggunakan unjuk kerja, observasi, wawancara, dan dokumentasi. Teknik uji validitas data yang digunakan adalah triangulasi sumber dan triangulasi teknik. Teknik analisis data yang digunakan dalam penelitian ini yaitu analisis data kuantitatif dengan menggunakan teknik analisis data komparatif untuk membandingkan persentase nilai kemampuan berbicara anak dari pratindakan, siklus I, siklus II dan siklus III, sedangkan analisis data kualitatif menggunakan model interaktif yang terdiri dari pengumpulan data, reduksi data, penyajian data dan penarikan kesimpulan.

\section{HASIL DAN PEMBAHASAN}

Kemampuan berbicara anak dari hasil pratindakan, siklus I, siklus II, hingga siklus III mengalami peningkatan. Hal itu terbukti dari unjuk kerja tiap siklusnya dari masingmasing indikator penilaian yaitu anak mampu menyusun kalimat, mampu berkomunikasi secara lisan menyebutkan peran serta atribut yang digunakan, mampu menjawab pertanyaan.

Hasil observasi kemampuan berbicara sebelum tindakan dapat disajikan pada tabel sebagai berikut:
KUMARA CENDEKIA Vol. 7 No. 4 Desember 2019 Tabel 1. Persentase Ketuntasan Klasikal Kemampuan Berbicara Pratindakan

\begin{tabular}{lll}
\hline $\begin{array}{l}\text { Kriteria } \\
\text { ketuntasan }\end{array}$ & F & Persentase \\
\hline Tuntas & 10 & $31,2,5 \%$ \\
\hline Belum Tuntas & 22 & $68,75 \%$ \\
\hline Jumlah & 32 & $100 \%$ \\
\hline
\end{tabular}

Berdasarkan tabel tersebut maka dapat dijelaskan bahwa jumlah ketuntasan keseluruhan kemampuan berbicara pada pratindakan anak terdapat 10 anak yang mendapat nilai tuntas sedangkan 22 anak memiliki nilai belum tuntas, hal ini disebabkan masih ada beberapa anak yang belum mencapai kriteria ketuntasan terhadap indikator kemampuan berbicara anak. Data tersebut dapat disimpulkan bahwa kemampuan berbicara anak masih rendah, hal ini dikarenakan ada beberapa faktor internal dan faktor eksternal yang mempengaruhi perkembangan kemampuan berbicara anak, sehingga perlu ditingkatkan berupaya untuk mengoptimalisasikan tingkat pencapaian perkembangan anak. Setelah pelaksanaan siklus I, terdapat peningkatan kemampuan berbicara anak. Terbukti dari tabel persentase ketuntasan klasikal kemampuan berbicara siklus I berikut ini: 
Tabel 2 Persentase Ketuntasan Klasikal Kemampuan Berbicara Siklus I

$\begin{array}{lll}\text { Kriteria } & \text { f }\end{array}$

\begin{tabular}{lll}
\hline Tuntas & 13 & $40,62 \%$ \\
\hline Belum Tuntas & 19 & $59,38 \%$ \\
\hline Jumlah & 32 & $100 \%$ \\
\hline
\end{tabular}

Berdasarkan tabel tersebut maka dapat diungkapkan bahwa persentase ketuntasan klasikal kemampuan berbicara pada siklus I sebanyak 13 anak mendapatkan nilai tuntas dan sebanyak 19 orang anak mendapatkan nilai belum tuntas dari tiga indikator yang telah ditentukan pada aspek kemampuan berbicara anak. Apabila dibandingkan dengan hasil persentase ketuntasan pratindakan maka kemampuan berbicara anak mengalami peningkatan sebanyak 9,37\%. Persentase ketuntasan klasikal pada siklus I belum memenuhi target pencapaian yang telah ditetapkan yaitu sebesar $\geq 76 \%$, maka dilakukan tindakan selanjutnya dengan melakukan refleksi sebelum melakukan siklus II.

Hasil refleksi dari siklus I yaitu: a) anak masih banyak yang tidak memperhatikan kelompok lain yang sedang melakukan kegiatan role play di depan kelas; b) anak-anak berebut dalam
KUMARA CENDEKIA Vol. 7 No. 4 Desember 2019 pemilihan peran; c) anak mudah lupa dengan naskah cerita yang disampaikan.

Berdasarkan hasil refleksi dari siklus I tersebut maka dapat diberikan solusi berupa: a) guru pendamping dan peneliti lebih tegas dalam mengkondusifkan kelas agar anak mau memperhatikan teman yang sedang berbicara di depan kelas; b) anakanak diberikan pengertian agar tetap mau bermain dan bisa bertukar peran dengan teman yang lain.

Siklus II mengalami peningkatan pada kemampuan berbicara anak kelompok B TK Gayabaru III Surakarta. Persentase klasikal kemampuan berbicara siklus II adalah sebagai berikut:

Tabel 3 Persentase Ketuntasan Klasikal Kemampuan Berbicara Siklus II

\begin{tabular}{lll}
\hline Kriteria & f & Persentase \\
& & \\
\hline Tuntas & 18 & $40,62 \%$ \\
\hline Belum Tuntas & 14 & $59,38 \%$ \\
\hline Jumlah & 32 & $100 \%$ \\
\hline
\end{tabular}

Berdasarkan tabel tersebut maka dapat diungkapkan bahwa persentase ketuntasan klasikal kemampuan berbicara anak pada siklus II terdapat sebanyak 18 anak mendapatkan nilai tuntas sedangkan 14 orang anak lainnya mendapatkan nilai belum tuntas. Persentase ketuntasan 
klasikal siklus II belum memenuhi target pencapaian yaitu sebesar $\geq 76 \%$, maka peneliti melanjutkan tindakan selanjutnya pada siklus III, untuk mencapai target dalam persentase ketuntasan.

Hasil refleksi dari siklus II tersebut maka dapat diberikan solusi, yaitu: a) anakanak di kelas saling berebut peralatan; b) anak yang latihannya tidak serius di awal kegiatan pembelajaran kemudian ngeblank pada saat kegiatan role play; c) anak yang jahil atau anak suka ramai masih berseliweran lewat di depan anggota atau tim yang sedang menjalankan kegiatan role play di depan kelas.

Berdasarkan hasil refleksi dari siklus II tersebut maka dapat diberikan solusi berupa a) guru memberikan pengarahan kepada anak untuk mau menunggu giliran; b) anak didorong oleh guru untuk membantu mengingat jalan ceritanya; c) guru memberikan pendampingan lebih intensif terhadap anak-anak yang masih jahil di kelas.

Perbaikan nilai pada kriteria ketuntasan anak dari siklus I dan siklus II sampai tahap siklus III mengalami peningkatan kembali pada kemampuan berbicara anak. Persentase klasikal kemampuan berbicara siklus III adalah sebagai berikut:
KUMARA CENDEKIA Vol. 7 No. 4 Desember 2019 Tabel 4 Persentase Ketuntasan Klasikal Kemampuan Berbicara Siklus III

Kriteria f $\quad$ Persentase

\begin{tabular}{lll}
\hline Tuntas & 25 & $78,12 \%$ \\
\hline Belum Tuntas & 7 & $21,88 \%$ \\
\hline Jumlah & 32 & $100 \%$ \\
\hline
\end{tabular}

Berdasarkan tabel tersebut maka dapat diungkapkan bahwa persentase ketuntasan klasikal kemampuan berbicara pada siklus III terdapat 25 anak mendapatkan nilai tuntas sedangkan 7 anak yang lainnya belum tuntas. Persentase ketuntasan klasikal pada siklus III sudah mencapai target pencapaian yang telah ditetapkan yaitu sebesar $\geq 76 \%$.

Kemampuan berbicara kelompok B TK Gayabaru III Surakarta mengalami peningkatan yang signifikan, berikut merupakan gambar diagram perbandingan

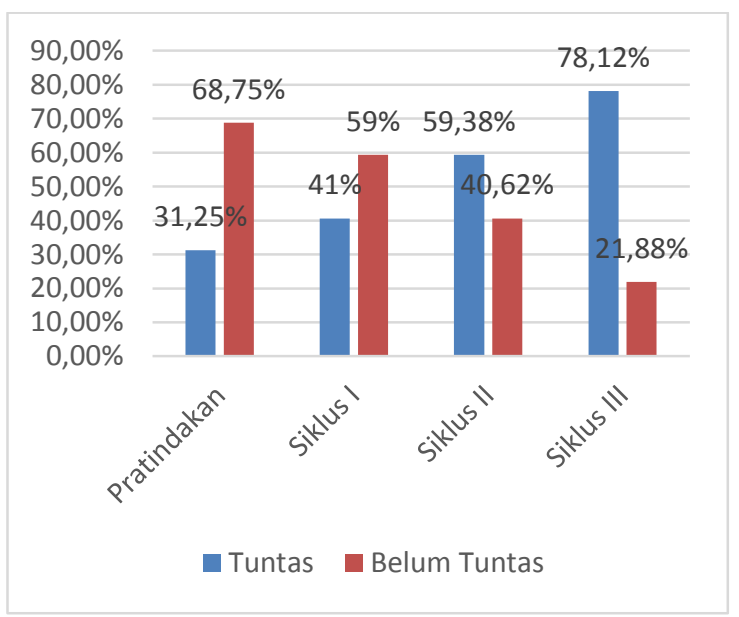


Gambar 1 Diagram Perbandingan Peningkatan Kemampuan Berbicara

Berdasarkan data dari gambar diagram tersebut maka perolehan ketuntasan kemampuan berbicara secara klasikal dari pratindakan, siklus I, siklus II, dan siklus III dapat dideskripsikan bahwa kemampuan berbicara pada pratindakan, persentase ketuntasan anak sebesar $31,25 \%$ atau 10 anak yang tuntas. Kemampuan berbicara anak pada siklus I mengalami peningkatan sebanyak $9,37 \%$ menjadi $40,62 \%$ atau sebanyak 13 anak yang memperoleh nilai tuntas. Peningkatan pada siklus II sebesar $16 \%$ menjadi $56,62 \%$ atau sebanyak 18 anak yang memperoleh nilai tuntas. Siklus III berlanjut dengan peningkatan sebesar $21,50 \%$ menjadi $78,12 \%$ atau sebanyak 25 anak. Keseluruhan peningkatan persentase ketuntasan kemampuan berbicara anak secara klasikal setelah diterapkan metode role play adalah sebesar $46,87 \%$.

Sebelum dilakukan tindakan, kemampuan berbicara anak belum berkembang secara optimal. Anak masih kesulitan dalam mencapai beberapa indikator kemampuan berbicara anak usia 5-6 tahun diantaranya anak dapat menyusun kalimat melalui pola S-P-O-K, anak mampu berkomunkasi secara lisan menyebutkan peran serta atribut yang digunakan, dan mampu menjawab
KUMARA CENDEKIA Vol. 7 No. 4 Desember 2019 pertanyaan mengenai $5 \mathrm{~W}+1 \mathrm{H}$ (apa, siapa, dimana, kapan, mengapa, dan bagaimana).

Berdasarkan hasil penelitian yang telah dilaksanakan oleh peneliti pada anak setelah dilakukan tindakan yaitu dengan menerapkan metode role play terdapat peningkatan pada kemampuan berbicara anak.

Temuan tersebut sejalan dengan pendapat dari Ngalimun dan Alfulaila (2014) kemampuan berbicara adalah sarana utama untuk anak mampu mengerti pesan yang disampaikan orang lain, dan adanya komunikasi timbal balik antara pembicara dengan pendengar. Salah satu metode yang bisa digunakan adalah melalui metode role play. Teori tersebut didukung dengan hasil penelitian dari Meacham, dkk (2014) menunjukkan bahwa anak-anak terlihat responsif pada saat menjawab pertanyaan pada saat berpartisipasi dalam kegiatan role play.

Berdasarkan hasil tindakan yang dilakukan setiap pertemuan dalam tiga siklus, peningkatan yang terjadi pada setiap aspek, dapat dilihat bahwa hasil peningkatan terendah dan anak sudah menguasai adalah pada indikator kemampuan menjawab pertanyaan yang kompleks. Indikator dalam menjawab pertanyaan yang lebih kompleks mengenai $5 \mathrm{~W}+1 \mathrm{H}$ pada indikator ini anak mengalami 
sedikit kesulitan dalam menjawab pertanyaan, kenyataannya sampai pada siklus III hanya terdapat empat anak yang mampu menjawab semua pertanyaan terkait denganiiapa, dimana, kapan, siapa, mengapa, dan bagaimana.

Kegiatan yang dilakukan menunjukkan bahwa pada indikator kemampuan menyusun kalimat sederhana dengan struktur lengkap melalui pola S-P-O-K setelah diadakannya tindakan pada setiap pertemuannya mengalami peningkatan secara signifikan sampai pada akhir pertemuan siklus ketiga anak dapat mencapai ketuntasan.

Indikator yang menyebutkan pada kemampuan berbicara secara lisan, masih ada enam anak yang belum tuntas, hal ini dikarenakan tipekal anaknya memang pendiam dan ada juga anak yang masih belum berani berbicara di depan kelas ada yang merasa takut dan malu berbicara dihadapan orang banyak. Faktor lain yang menyebabkan anak pendiam dan pemalu ini adalah faktor di lingkungannya, karena anak tersebut jarang bersosialisasi dengan lingkungan sekitar, selain itu anak juga cenderung tertutup terhadap orang lain.

Berdasarkan hasil pengamatan dari peneliti, ketika kegiatan role play berlangsung anak-anak masih terlihat banyak yang berebut peran dengan teman
KUMARA CENDEKIA Vol. 7 No. 4 Desember 2019 lainnya, ada juga anak yang tidak mau maju ke depan kelas, dan terdapat juga anak yang memilih-milih teman untuk menjadi satu kelompok dalam kegiatan role play.

Hal tersebut sesuai (Sanjaya, 2013) yang menjelaskan bahwa ada beberapa faktor yang mempengaruhi kemampuan berbicara meliputi faktor internal dan faktor ekternal. Faktor internal seperti kesehatan, minat, motivasi, bakat, kecerdasan, keinginan berkomunikasi, dan kepribadian anak. Faktor eksternal meliputi guru, keadaan sosial keluarga, lingkungan sosial masyarakat, lingkungan sekolah, metode pelatihan anak, dan hubungan dengan teman sebaya.

Kepribadian merupakan keseluruhan sikap, ekspresi, dan perilaku yang dimiliki seseorang (Rusman, 2017), perilaku tersebut akan terbukti pada perbuatan seseorang apabila anak dihadapkan dengan situasi tertentu.

Temuan lain yang peneliti temukan yaitu metode role play mempengaruhi terhadap aspek pada kemampuan sosial anak usia dini (Aulina, 2015). Kemampuan sosial merupakan suatu cara anak mengelola emosinya dengan orang lain dan suatu cara yang dilakukan untuk memberikan kesempatan pada anak meningkatkan secara optimal potensi- 
potensi yang dimiliki oleh anak melalui minat dan bakatnya.

Sejalan dengan hal tersebut Martani dan Sita (2015) telah menjelaskan bahwa metode role play dapat meningkatkan pengetahuan perilaku prososial pada anak usia dini, perilaku tersebut sangat penting untuk membentuk hubungan sosial yang positif dalam kehidupan bermasyarakat. Perilaku prososial mempengaruhi anak dalam menyesuaikan diri dengan lingkungannya, memiliki coping yang baik dan kontrol diri terhadap orang lain. Salah satu tujuan langsung dari metode role play yaitu meningkatnya kemampuan berbicara anak. Temuan lain selain kemampuan berbicara yang meningkat, aspek kecerdasan interpersonal, kemampuan sosial, dan perilaku prososial juga dapat ditingkatkan melalui metode role play.

\section{SIMPULAN}

Berdasarkan hasil penelitian tindakan kelas yang telah dilaksanakan dalam tiga siklus dengan menerapkan kegiatan pembelajaran melalui metode role play terdapat peningkatan persentase ketuntasan kemampuan berbicara dalam setiap siklusnya pada indikator kemampuan berbicara anak usia 5-6 tahun yaitu hasil penelitian tindakan kelasi ni menunjukkan bahwa melalui metode role play, anak dapat
KUMARA CENDEKIA Vol. 7 No. 4 Desember 2019 menyusun kalimat melalui pola S-P-O-K, mampu berkomunkasi secara lisan menyebutkan peran serta atribut yang digunakan, menjawab pertanyaan mengenai $5 \mathrm{~W}+1 \mathrm{H}$ (apa, siapa, dimana, kapan, mengapa, dan bagaimana).

Kemampuan berbicara anak pada pratindakan memiliki persentase ketuntasan sebesar $31,25 \%$ atau sebanyak 10 anak yang memperoleh nilai tuntas. Kemampuan berbicara anak pada siklus I mengalami peningkatan sebanyak 9,37\% menjadi 40,62\% atau sebanyak 13 anak yang memperoleh nilai tuntas. Peningkatan pada siklus II sebesar $16 \%$ menjadi $56,62 \%$ atau sebanyak 18 anak yang memperoleh nilai tuntas. Siklus III berlanjut dengan peningkatan sebesar $21,50 \%$ menjadi $78,12 \%$ atau sebanyak 25 anak.

Keseluruhan peningkatan persentase ketuntasan kemampuan berbicara anak secara klasikal setelah diterapkan metode role play adalah sebesar $46,87 \%$. Berdasarkan data tersebut, maka bisa diambil simpulan melalui metode role play mampu meningkatkan kemampuan berbicara pada anak usia 5-6 tahun TK Gayabaru III Surakarta.

Berdasarkan kesimpulan hasil penelitian, maka peneliti menyampaikan 
beberapa saran yang diharapkan dapat memberikan manfaat yaitu:

1. Bagi anak

Anak dapat meningkatkan kemampuan berbicaranya dalam menyusun kalimat melalui pola S-P-O-K, mampu berkomunkasi secara lisan menyebutkan masing-masing peran dan pekerjaan termasuk didalamnya perlengkapan atau atribut dan tugastugas yang dilakukannya dalam pekerjaan tersebut, serta anak mampu menjawab pertanyaan.

2. Bagi guru

a. Guru dapat menerapkan metode role play dalam kegiatan pembelajaran, dalam satu pekan diberikan dua kali pertemuan untuk melakukan metode role play.

b. Guru memilih kegiatan role play yang dapat diterapkan sesuai dengan tema pembalajaran, pemilihan tema sangat mempengaruhi kelancaran kegiatan pembelajaran.

3. Bagi sekolah

a. Sekolah hendaknya dapat memberikan fasilitas yang dibutuhkan guru untuk melaksanakan kegiatan role play.
KUMARA CENDEKIA Vol. 7 No. 4 Desember 2019

b. Sekolah dapat memberikan perhatian guru dalam memperkaya kegiatan pembelajaran untuk menggunakan metode role play.

4. Bagi peneliti selanjutnya

Peneliti selanjutnya dapat mengembangkan melalui metode yang lainnya yaitu dengan menggunakan metode role play mikro, serta lebih memperhatikan aspek-aspek yang dapat ditingkatkan melalui metode role play untuk anak usia dini.

\section{DAFTAR PUSTAKA}

Abidin, Y. (2012). Pembelajaran bahasa berbasis Pendidikan Karakter. Bandung: PT Refika Aditama.

Aulina, C.N. (2015). Pengaruh bermain peran terhadap kemampuan sosial anak usia dini. Jurnal Pedagogia. 4 (1), 59-69.

Bleses, D., dkk. (2018). An educatoradministered measure of language development in young children. Infant Behavior and Development, 52, 104-113.

Joyce, B., Weil, M., \& Calhoun, E. (2015). Models of teaching. Englewood Cliffs, New Jersey: Prentice Hall, Inc. 
Madyawati, L. (2016). Strategi pengembangan bahasa pada anak. Jakarta: Prenadamedia Group.

Martani, W. \& Alfiyah, S. (2015). Validasi modul bermain peran "aku sayang kawan" untuk meningkatkan pengetahuan perilaku prososial pada anak usia dini. Journal of Professional Psychology. 1 (2), 120-137.

Meacham, S., dkk. (2014). Preschool teachers' questioning in sociodramatic play. Early Childhood Research Quarterly. 29, 562-573.

Mursid. (2017). Pengembangan pembelajaran PAUD. Bandung: PT. Remaja Rosdakarya Offset.

Ngalimun \& Alfulaila, N. (2014). Pembelajaran keterampilan berbahasa indonesia. Yogyakarta: Aswaja Pressindo.

Rusman. (2017). Belajar \& pembelajaran: berorientasi standar proses pendidikan. Jakarta: Kencana.

Sanjaya, W. (2013). Perencanaan dan desain sistem pembelajaran. Jakarta: Kencana.
KUMARA CENDEKIA Vol. 7 No. 4 Desember 2019 Seefeldt, C. \& Wasik, B. (2008). Pendidikan anak usia dini. Jakarta: PT. Indeks.

Soetjiningsih. (2014). Tumbuh kembang anak. Jakarta: Penerbit Buku Kedokteran EGC.

Sugito \& Saleh, S.M. (2015). Implementasi metode bermain peran untuk meningkatkan kecerdasan interpersonal anak usia 5-6 Tahun di TK barunawati. Jurnal Pendidikan dan Permberdayaan Masyarakat. 2 (1), 85-93.

Tahmores, A. (2011). Role of play in social skills and intelligence of children. Procedia - Social and Behavioral Sciences 30, $2272-2279$

Tarigan, H.G. (2013). Berbicara sebagai suatu keterampilan berbahasa. Bandung: CV. Angkasa.

Uno, H. (2012). Model pembelajaran. Jakarta: Bumi Aksara.

Zaini, H., Munthe, B., Aryani, S.A. (2008). Strategi pembelajaran aktif. Yogyakarta: Pustaka Insan Madani 
KUMARA CENDEKIA Vol. 7 No. 4 Desember 2019 